The Venetian Qur'an 


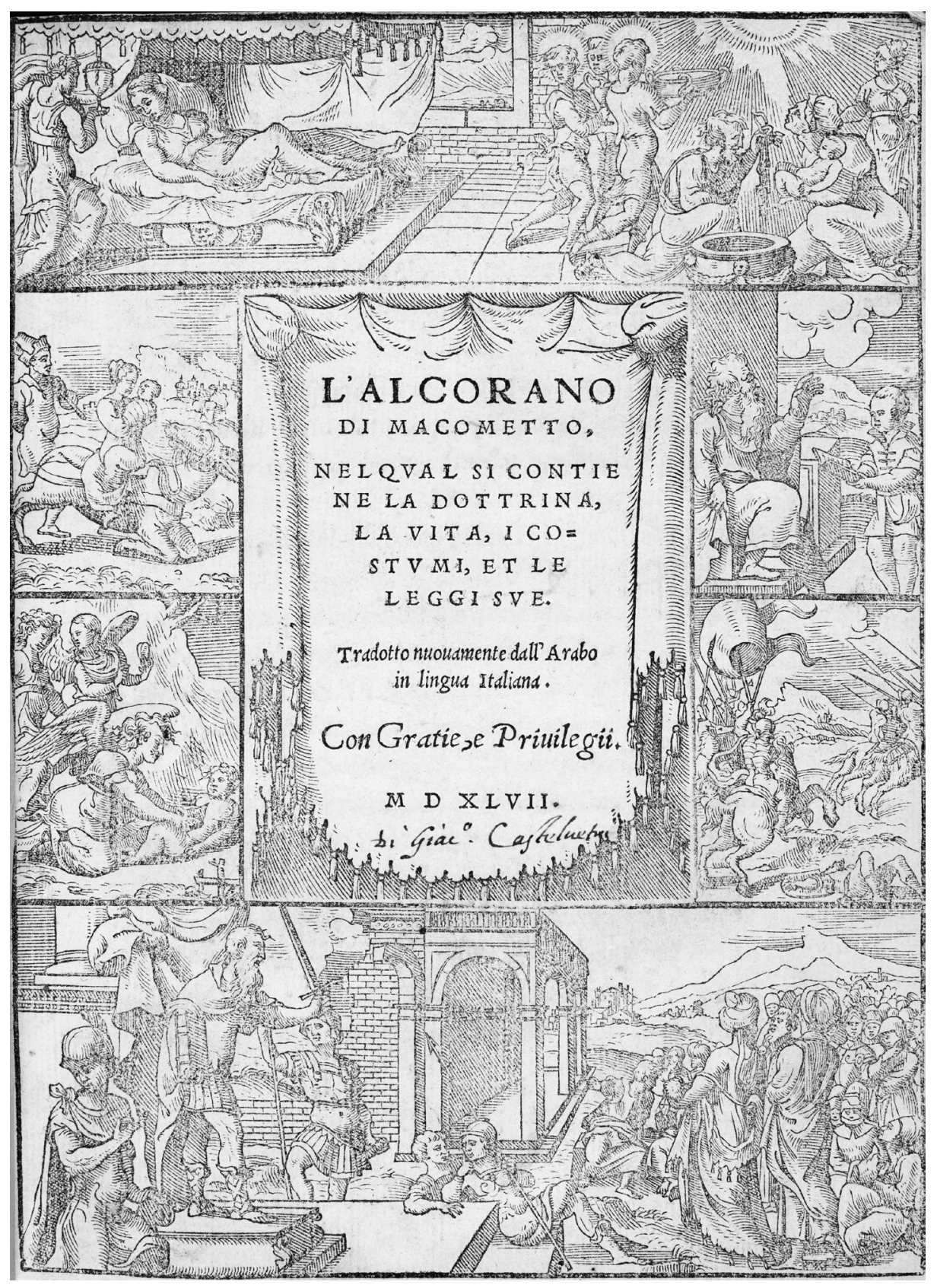




\section{The Venetian Qur'an}

A RENAISSANCE COMPANION TO ISLAM

Pier Mattia Tommasino

Translated by Sylvia Notini

$\overline{\text { PENN }}$

UNIVERSITy OF PENNSYlVANIA PRESS Philadelphia 


\section{MATERIAL TEXTS}

SERIES EDITOR S

$\begin{array}{ll}\text { Roger Chartier } & \text { Leah Price } \\ \text { Joseph Farrell } & \text { Peter Stallybrass } \\ \text { Anthony Grafton } & \text { Michael F. Suarez, S.J. }\end{array}$

A complete list of books in the series is available from the publisher.

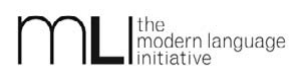

THIS BOOK IS MADE POSSIBLE BY A COLLABORATIVE GRANT

FROM THE ANDREW W. MELLON FOUNDATION.

Originally published as L'Alcorano di Macometto: Storia di un libro del Cinquecento europeo by Pier Mattia Tommasino @ Il Mulino 20I3

English translation copyright ( $(2) 2018$ University of Pennsylvania Press

All rights reserved. Except for brief quotations used for purposes of review or scholarly citation, none of this book may be reproduced in any form by any means without written permission from the publisher.

Published by

University of Pennsylvania Press

Philadelphia, Pennsylvania I9I04-4II 2

www.upenn.edu/pennpress

Printed in the United States of America on acid-free paper

IO $9 \begin{array}{lllllllll} & 8 & 7 & 6 & 5 & 4 & 3 & 2 & \text { I }\end{array}$

A catalogue record for this book is available from the Library of Congress.

ISBN 978-0-8I22-50I2-I

Frontispiece: Title page of L'Alcorano di Macometto (Venice, I547), Copenhagen, Det Kongelige Bibliotek, 28.270 . 